МЕТОДЫ

\title{
Interaction of cyanine dyes with nucleic acids. 5. Towards model of «half intercalation» of monomethyne cyanine dyes into double-stranded nucleic acids
}

\author{
Sergiy M. Yarmoluk, Vladyslava B. Kovalska, Yury P. Kovtun ${ }^{1}$ \\ Institute of Molecular Biology and Genetics, National Academy of Sciences of Ukraine \\ I50 Zabolotnoho str., 252143, Kyiv, Ukraine \\ Institute of Organic Chemistry, National Academy of Sciences of Ukraine \\ 5 Murmanska str., 253660, Kyiv, Ukraine
}

\begin{abstract}
Recently we have proposed a model of "half intercalation" of monomethyne cyanine dive into the double-stranded helix. Benzothiazole terminal heterocyclc "clissically" intercalates, nestled between the adjacent base pairs just when second heterocycle is spatially fixed by nucleic acid groove. We consider that heterocycle with high basicity hits in the more nucleophilic groove whereas heterocycle with low basicity insert in more electrophilic interbase space. The purpose of this study is to determine the possible fixation mode of second heterocycle in nucleic acid groove. We synthesized and investigated the siries of structure-iike cyanine dyes which have different charge electronic distribution. We suppose that binding of second heterocycle of high basicity is caused by both spatial fixation and electrostatic interaction with phosphate group of nucleic acid. Monomethyne pyriainium cyanine dye (Cyan 40; 4-!(1-methylbenzothiazoleilidene-2)methyl'-1,2,6-trimethylpyridinium p-toluenesulfonate inieracted with lative DNA and RNA with strong fluorescence enhancement. It seems to be perspective for the development of new nucleic acid binding cyanine dyes.
\end{abstract}

Introduction. The qualitative and quantitative determination of nucleic acids is of great significance for detection of pathogenic organisms (bacteria, viruses) [1], determination of mutated genes (hereditary diseases, such as diabetes mellitus, phenylketonuria, and sickle cell anemia) [2], and solving of sexual crimes in forensic medicine [3]. Radioisotopes are widely used in the most approaches for the detection of nucleic acids. The numerous disadvantages of radioactive detection such as the handling licenses required, disposal costs, precautions necessary to prevent risks to health, short shelf-life have contributed to shifting the emphasis towards development of nonradioactive methods.

Fluorescent cyanine dyes are very promising for the development of new nonradioactive approaches of labeling and detection of nucleic acids. They are

(C) S. M. YARMOLUK, V. B. KOVALSKa, Yu. P. KOVTUN, 1999 increasingly used for fluorescent microscopy, DNA sequencing [4], staining nucleic acids in gel electrophoresis [.5].

Monomethyne cyanines are weakly fluorescent in free state but show strong fluorescence upon binding to DNA or RNA, and some of these dyes are the most sensitive nucleic acid stains currently available $[6,7]$. Today commercial availability of highly sensitive spectroscopic apparatus promotes development of new homogeneous approach of nucleic acids determination. Capillary electrophoresis represents an additional improvement in assays of nucleic acids compared with conventional gel electrophoresis systems [8].

In homogeneous analysis there is no separation of fluorescence probe excess and there is record of fluorescence signal changing upon forming of probenucleic acids complex. The strong enhancement of fluorescence of dye molecules is the result of decreased rotational mobility around the internuclear 
bridge between the two aromatic ring systems of the dye chromofore [9].

The possible fixation mode is main question of any model of cyanine dyes interaction with nucleic acidis. Jacobsen at al. [10] proposed «interaction model» of binding of TOTO to dsDNA involving the insertion of dye into the interior of the helix with a coniugated ring system nestled between the adjacent base pairs of the DNA. It was shown that the binding of TOTO to larger oligonucleotides is site selective with CTAG : CTAG as preferred binding site [10]. In this model dye fixation is caused only by intercalation mechanism.

Recently Rye and Glazer have proposed a «partial intercalation» model of TOTO binding to DNA to explain stability and spectroscopic properties of TOTO - ssDNA complexes. In their model the nucleic acid serves as a scaffold upon which highly cooperative dye-base-dye stack aggregates are formed. In their model dye fixation is caused by both stacking and intercalation mechanisms [10].

In our previous study we developed the possible "half intercalation" model of monomethyne benzthiazole cyanine dyes binding with double-stranded nucleic acids. We proposed that dye fixation is the result of both intercalation mechanisms and steric fitting of dye in nucleic acid groove [11 ]. In this work we show that electrostatic interaction of high basicity hetorocycle with phosphate groups of nucleic acids may be possible mode of dye fixation too.

Materials and Methods. Spectroscopic measurements. The absorption spectra were obtained on Spccord M-40 (Germany). Absorption of free dyes was measured immediately after dissolving dimethylsulfoxide (DMSO) dye stock solution in appropriate solvents: $50 \mathrm{mM}$ Tris- $\mathrm{HCl}$, pH 6 or DMFA. Fluorescence spectra were recorded with a serial fluorescence spectrophotometer Hitachi Model 850 (Japan). Fluorescence measurements were carried out in thermostable quartz cell $(0.5 \times 0.5 \mathrm{~cm})$. Fluorescence was excited with a 150 Watt Xe-lamp emission.

Preparation of DNA, RNA and dyes stock solulions. Stock solution of dyes $\left(2 \cdot 10^{-1} \mathrm{M}\right)$ were piepared by dissolving dyes in DMSO. All dyes were stable in this solvent for several months, whereas in :1queous solutions some dyes gradually lost their fluorescence properties. Working solutions were preparted immediately prior to use. For spectral studies total calf thymus DNA ( Sigma», LSA) and yeast RNA («Sigma») were used. Nucleic acids stock solutions were prepared in TE buffer $(50 \mathrm{mM}$ Tris- $\mathrm{HCl}$, $10 \mathrm{mM}$ EDTA, pH 8.0) in concentration $6.1 \cdot 10^{-3} \mathrm{~b}$. p. for DNA and $1.2 \cdot 10^{-2}$ b. p. for RNA.

Absorbance and fluorescent emission spectra. For spec1ral measurements the complexes of dyes with nucleic acids were obtained by mixing dye stock solution with DNA or RNA solution in Tris- $\mathrm{HCl}(50$ $\mathrm{mM}, \mathrm{pH} \mathrm{6)}$ buffer. The final concentration of DNA an RNA was $1.2 \cdot 10^{-4}$ and $2.4 \cdot 10^{-4} \mathrm{M}$ respectively. Final dyes concentrations were $0.02 \mathrm{mM}$. Dye-nucleic acid complexes were prepared with approximate ratio of 1 dye per 12 base of RNA and 6 b. p. of DNA. Fcr measurement of optical properties of free cyanines the same dyes concentrations were used.

Preparation of cyanine dyes. Standard procedures were used for the synthesis of unsymmetrical monomethyne cyanines [13]. The purity of synthesized dyes was controlled by UV-spectroscopy and elemental analysis.

$p H$ Investigation. Two procedures were used to study $\mathrm{pH}$ effect on spectral properties of dye/DiNA complexes. In the first procedure dye/DNA complexes were prepared by adding dye stock sclution to DNA working solution at $\mathrm{pH} 6$. The?: $\mathrm{pH}$ of solution was changed to $\mathrm{pH} 5$ by adding the corresponding amount of $0.05 \mathrm{M} \mathrm{CH}_{3} \mathrm{COOH}$ or to $\mathrm{pH} 9$ by adding $0.1 \mathrm{M} \mathrm{NaOH}$. In second procedure $\mathrm{pH}$ of DNA solution (50 mM Tris- $\mathrm{HCl}, \mathrm{pH}$ 6) was previousiy changed to $\mathrm{pH} 5$ or $\mathrm{pH} 9$ and then dye stock solution was added.

Results. Dye structures and spectrosconic proper ties of free dyes. Physical data for three synthesized cyanine dyes (Cyan 39, Cyan 40 and Cyan 37), ays base (Cyan 42), salt of dye base (Cyan 41) and TO are presented in Table 1. The fluorescent pioperites of these dyes and their complexes with nucieic acids have not been previously studied. Dye TO with well investigated spectral properties was included for the comparison [14]. The wavelengths of abserption maximum $\left({ }^{\mathrm{mol}} \lambda_{\mathrm{max}, \mathrm{x}}\right)$ of benzothiazole cyanines slightly depend on solvent. Absorption maxima of the dyes showed the red shift of 2-8 $\mathrm{nm}$ after going from aqueous buffer to less polar DMFA. The fluorescence intensity $\left(I_{0}\right)$ of free dyes is very low and have no clear maximum $\left({ }^{\mathrm{em}} \lambda_{\max }\right)$ and Stokes shift $(\Delta S)$. Cyan $39,40,41$ and TO have a strong tendency to form $\mathrm{H}$-aggregates in water buffer $\left({ }^{\mathrm{agr}} \lambda_{\max }\right)$ in contrast to unpolar DMFA. Cyan 37 with polar carboxyl group aggregates weakly.

$N A$-Interaction properties of dyes. The data on the absorbance and fluorescence emission spextra of the nucleic acid-bound form of dyes are presented in Table 2. All dyes had low Stokes shifis $(\Delta S, 28.0-$ $78.0 \mathrm{~nm}$ ). Nucleic acid presence does not influence on absorption maximum ( $\left({ }^{\mathrm{abs}} \lambda_{\max }\right)$ of dye $\left({ }^{\mathrm{abs}} \lambda_{\max }\right.$ (complex) $-{ }^{\mathrm{mol}} \lambda_{\max }$ (free); $0-4 \mathrm{~nm}$ ).

The Cyan 40 with 1,2,6-trimethylpyridinium heterocycle has the most promising characteristics for 
Table 1

Chemical structures and spectroscopic properties of cyanine dyes

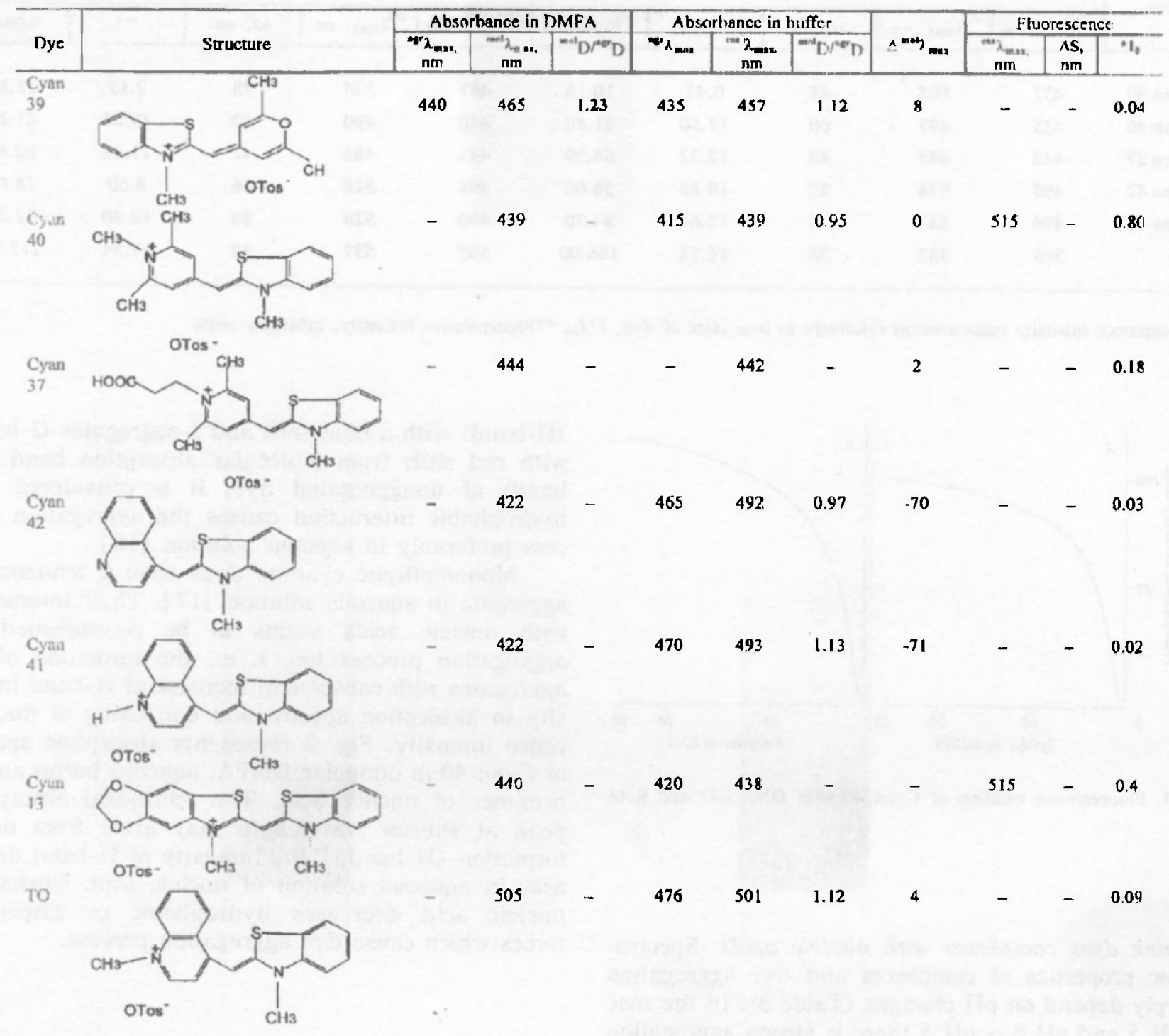

the nucleic acids analysis. Its fluorescence intensity $(n)$ is equal for DNA and 2.5-fold greater for the RNA than that of TO. Unfortunately, dye has high fluorescence in free state $(0.8)$ in contrast to TO $(0.09)$. It is not efficient for the homogeneous system detection $\left(\Delta Q_{\mathrm{DNA}}=21.8, \Delta Q_{\mathrm{RNA}}=61.25\right)$ in contrast to $\mathrm{TO}$ $\left(\Delta Q_{\mathrm{DNA}}=186.0, \Delta Q_{\mathrm{RNA}}=217.1\right)$.

Titration of Cyan 40 with DNA and RNA. Fluorescence titration of Cyan 40 was carried out in $0.05 \mathrm{M}$ Tris buffer ( $\mathrm{pH} \mathrm{6)}$ with total calf thymus
DNA and yeast RNA at 495 and $490 \mathrm{~nm}$ respectively (Fig. 1). The fixed dye concentration was $2 \cdot 10^{-5} \mathrm{M}$. The DNA and RNA concentration was changed from $2.9 \cdot 10^{-6}$ to $4.1 \cdot 10^{-4} \mathrm{M}$ and from $1.1 \cdot 10^{-5}$ to $9.1 \cdot 10^{-4}$ respectively. For the Cyan 40-DNA complexes fluorescence plateau is reached at 6 base pairs per dye (A). Titration of RNA showed that the fluorescence emission of bound Cyan 40 reaches a maximum at 10 base/dye (B).

pH-Influence on the spectroscopic properties of 
Table 2

Spectroscopic properties of cyanine dyes complexes with nucleic acids

\begin{tabular}{|c|c|c|c|c|c|c|c|c|c|c|}
\hline Dye & \multicolumn{5}{|c|}{ DNA-Dye complex } & \multicolumn{5}{|c|}{ RNA-Dye complex } \\
\hline Cyan 40 & 435 & 495 & 60 & 17.50 & 21.80 & 440 & 490 & 50 & 49.05 & 61.25 \\
\hline Cy an 37 & 442 & 485 & 43 & 12.32 & 68.00 & 442 & 483 & 41 & 11.28 & 62.67 \\
\hline TO & 505 & 532 & 28 & 16.78 & 186.00 & 505 & 537 & 32 & 19.54 & 217.10 \\
\hline
\end{tabular}

'Fluorescence intensity enhancement relatively to free state of dye, $I / I_{0} ;{ }^{* *}$ Fluorescence intensity, arbitrary units.

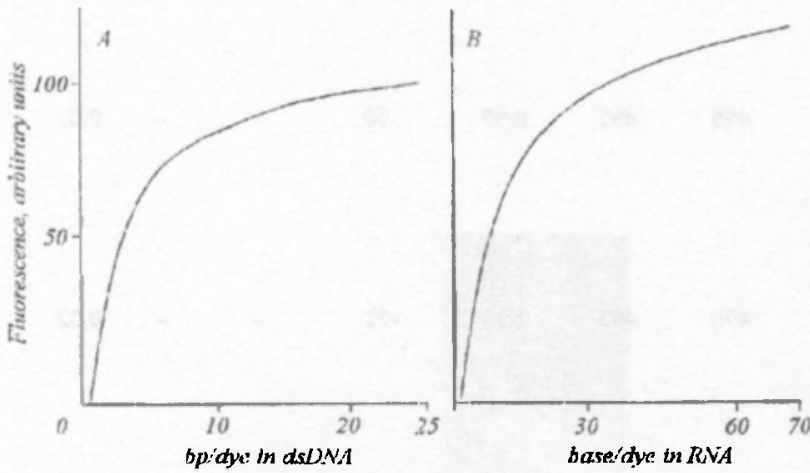

Fig. 1. Fluorescence titration of Cyan 40 with DNA $(A)$ and RNA (B)

yanine dyes complexes with nucleic acids. Spectroscopic propertics of complexes and dye aggregation sharply depend on $\mathrm{pH}$ changes (Table 3 ). In the case of $\mathrm{pH} 5$ and $\mathrm{pH} 6 \rightarrow \mathrm{pH} 5$ there is strong aggregation $\left.{ }^{\mathrm{mol}} D / /^{\mathrm{agr}} D<1\right)$ in absorption spectra of dye-nucleic acid complexes. Consequently', fluorescence intensities a.t $\mathrm{pH} 5$ are 3-10 times lower than at $\mathrm{pH} 6$.

For the $\mathrm{pH} 9$ and $\mathrm{pH} 6 \rightarrow \mathrm{pH} 9$, fluorescence intensities of complexes slightly decrease as compare to $\mathrm{fH} 6$, but in absorption spectra molecular peaks increase $\left({ }^{\text {mol }} D /^{\mathrm{agr}} D>1\right)$.

Discussion. The spectral characteristics of ionic cyanine dyes can depend on their concentration or counterion nature. In this case their disobey of Beer's law and change of their absorption characteristics were caused by the aggregation process [15], i. e., the formation of dimers, trimers, and $n$-mers. The aggregates of polymethyne dyes divided into $\mathrm{H}$-aggregates
(H-band) with a blue shift and J-aggregates (J-band) with red shift from molecular absorption band $(M-$ band) of unaggregated dye. It is considered that hydrophobic interaction causes the aggregation process preferably in aqueous solution [16].

Monomethyne cyanine dyes have a tendency to aggregate in aqueous solution [17]. Their interaction with nucleic acids seems to be accompanied by aggregation process too, i. e., the formation of $\mathrm{H}$ aggregates with consequent increase of $\mathrm{H}$-band intensity in absorption spectra and quenching of fluorescence intensity. Fig. 2 represents absorption spectra of Cyan 40 in nonpolar DMFA, aqueous buffer and in presence of nucleic acid. The additional absorption peak at shorter wavelength may arise from dine. formation ( $\mathrm{H}$-band, ${ }^{a g} D$ ). Intensity of $\mathrm{H}$-band decreases in aqueous solution of nucleic acid. Obviously, nucleic acid decreases hydrophobic or dispersion forces which cause dye aggregation process.

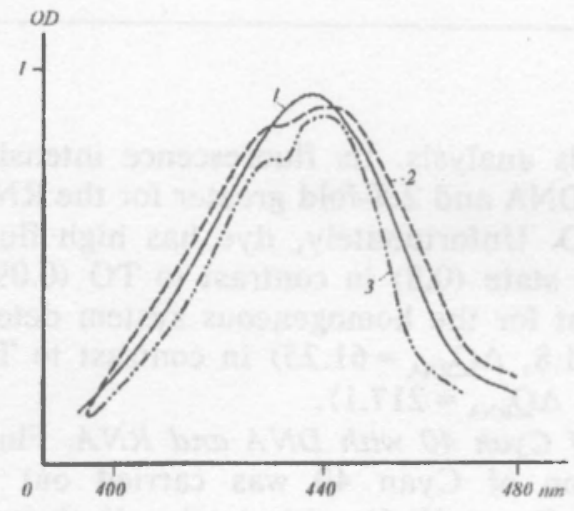

IFig. 2. Absorption spectra of $\mathrm{Cy}$ an 40 in buffer (I), DMFA (2) and DNA present (3) 
Table 3

Dependence of the spectroscopic properties of cyanine dyes-nucleic acids complexes on pH of working solutions and procedure of their preparation

\begin{tabular}{|c|c|c|c|c|c|}
\hline Dye & ${ }^{\mathrm{agr}} \mathrm{\lambda}_{\max }$ & $\operatorname{mol}_{\lambda_{\max }}$ & ${ }^{\mathrm{mol}} I / I^{\mathrm{agl} I}$ & $\mathrm{em}_{\lambda_{\max }}$ & थ \\
\hline \multicolumn{6}{|c|}{$\rho H 6$} \\
\hline Cyan 41 & 476 & 496 & 1.4 & 530 & 9.64 \\
\hline Cyan 42 & 472 & 496 & 1.03 & 528 & 8.82 \\
\hline TO & 489 & 505 & 1.5 & 532 & 13.78 \\
\hline \multicolumn{6}{|c|}{$p H S$} \\
\hline Cyan 41 & 470 & 498 & 0.84 & 525 & 2.87 \\
\hline Cyan 42 & 467 & 495 & 0.64 & 545 & 1.02 \\
\hline To & 480 & 505 & 0.81 & 555 & 0.98 \\
\hline \multicolumn{6}{|c|}{$p H 6 \rightarrow p H S$} \\
\hline Cyan 41 & 470 & 498 & 1.00 & 528 & 4.01 \\
\hline Cyan 42 & 469 & 495 & 0.76 & 523 & 1.30 \\
\hline TO & 475 & 502 & 1.06 & 550 & 1.10 \\
\hline \multicolumn{6}{|c|}{$p H 9$} \\
\hline Cyan 41 & 460 & 500 & 1.12 & 525 & 9.2 \\
\hline Cyan 42 & 436 & 460 & 1.28 & 525 & 7.98 \\
\hline TO & 482 & 509 & 1.44 & 538 & 9.31 \\
\hline \multicolumn{6}{|c|}{$p H 6 \rightarrow p H 9$} \\
\hline Cyan 41 & 475 & 500 & 1.43 & 525 & 9.2 \\
\hline Cyan 42 & 465 & 498 & 1.35 & 525 & 9.78 \\
\hline To & 480 & 508 & 1.35 & 535 & 10.10 \\
\hline
\end{tabular}

Data presented in Table 3 show that increase of $\mathrm{H}$-band intensity relatively to that of $\mathbf{M}$-band causes decrease of fluorescence intensity. All well interacted with nucleic acids monomethyne cyanine dyes seem to possess a high aggregation tendency in water solution and aggregation decreases after their interaction with nucleic acids [18].

However, little is known about influence of aggregation interaction mechanism and possible model of cyanine dyes binding with nucleic acids. Recently proposed models of interaction of cyanine dyes with nucleic acids do not take into account aggregation processes [10]. Besides, existence of $\mathrm{H}$-band of $\mathrm{H}$-aggregate at high dye : DNA ratios was the basis for the development of new binding mode of YOYO with doutle-stranded DNA [19]. We assume that dirner formation and interaction with any substrate surface can explain a blue shift in absorption spectra of YOYO-nucleic acid complexes [20].

Recently Rye and Glazer proposed «a partial intercalation-like» model of interaction of cyanine dyes with single-stranded nucleic acids. In their model, single-stranded polymer serves as a scaffolds upon which highly cooperative dye-base-dye stack aggregates are formed. This model is in gcod agreement with possible dye aggregation, i. e., it explains blue shifts in absorption spectra of the boundecl dyes and quenching in fluorescence spectra [11]. 
Obviously, stacking of cyanine dyes causes formation of aggregate structures like dye-dye, dye-dyebase and dye-base-dye uncler interaction of monomethyne cyanines dyes with double-stranded nucleic acicls too. Titration of fixed amount of Cyan 13 with dsDNA $(A)$ and titration of fixed amount of the same dsDNA with the same dye $(B)$ were represented on Fig. 3.

Absorption and fluorescence spectra are not identical in the cases $A$ and $B$. Titration of fixed amount of Cyan 13 with dsDNA changes only absorbance and fluorescense intensities, whereas reverse titration le-ads to spectral patterns changes. New $\mathrm{H}$-aggregate structures at ratio $2: 1 \mathrm{dye} / \mathrm{b}$. p. are formed in the case $B$. In absorbance spectrum peaks at $420-440 \mathrm{~nm}$ decrease and new peak at $400 \mathrm{~nm}$ appears. Aggregation process is accompanied by quenching of main
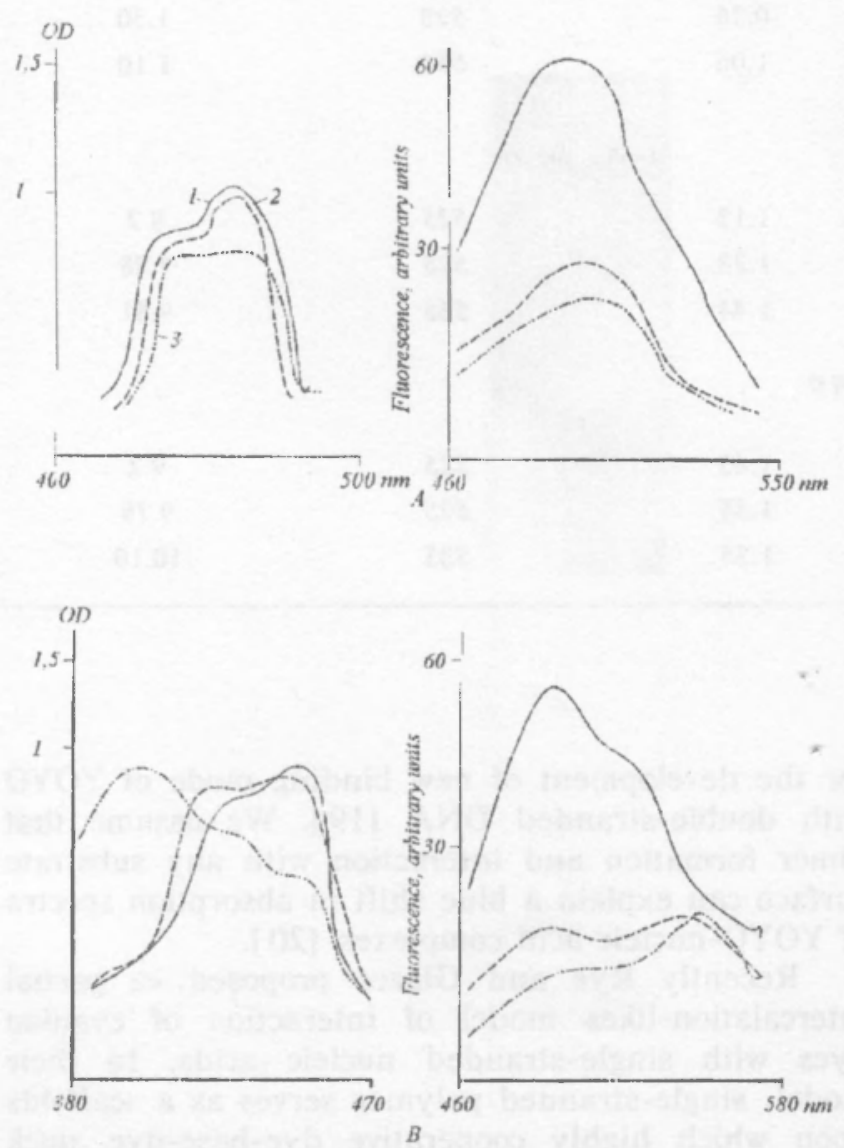

Fig. 3. Absorption and fluorescence spectra of Cyan 13. Aitration of fixed amount of Cyan 13 with dsDNA; $B$ - titration of fixed amount of the same dsDN.A with the same dye. Dye:b. p. ritios are $1: 7(1) ; 1: 1(2) ; 2: 1(3)$ fluorescence peak $(495 \mathrm{~nm})$ and appearance new red shifted peak $(540 \mathrm{~nm})$ with low intensity.

Double-stranded nucleic acids seem to serve as scaffold for the formation dye-dye-base and dye-dyedye-base aggregates like in Rye's model [11] for single-stranded nucleic acids. We suppose the process of formation of $\mathrm{H}$-aggregates with $n>2$ begins at some excess of dye with participation of some structure elements of nucleic acid.

Recently we have developed the «half intercalation» model of interaction of monomethyne cyanine dyes with double-stranded nucleic acids. We proposed that one heterocycle of cyanine dye intercalates into the interior of the helix whereas second heterocycle is fixed in nucleic acid groove. According to this model, less basic hetercycle intercalates and fixation of more basic one appears to be the result of coulombic interaction with negative phosphate groups of nucleic acid [12].

In order to explain the possible fixation mode of basic heterocycle in the groove space we synthesized a series of structure-like cyanine dyes (Table 1). Unsymmetrical monomethyne pyrylium (Cyan 39) and pyridinium (Cyan 40 ) cyanine dyes have very similar chemical structures. The pyrylium heterocycle of Cyan 39 has however low basicity as compared to pyridinium moiety of Cyan 40 . As a resul! interaction of Cyan 40 with nucleic acids leads to enhanced fluorescence increase. Due to the presence of $\mathrm{COOH}$ group in Cyan 37 its interaction with nucleic acids and therefore fluorescence intencity of dye-nucleic acid complexes are lower than those of Cyan 40 .

TO, its base (Cyan 42) and salt of this base (Cyan 41) have analogous chemical structures (Table 1). In this series, $T O$ and Cyan 41 have similar electronic charge distribution. Acidification of Cyan 42 (base) at $\mathrm{pH} 5$ protonates benzthiazole heterocycle to yield Cyan 41 (salt). In basic environment ( $\mathrm{pH}$ 9) Cyan 41 (salt) is converted into Cyan 42 (base). The $\mathrm{pH}$-depended absorption spectra of cyanine base and their salt clearly show large red or blue shifts caused by base-into-salt or salt-into-base conversion (Fig. 4).

Two procedures were used to prepare working solution of dye/DNA complexes. In the first procedure, dye/DNA complexes were prepared by adding dye stock solution to nucleic acid solution at $\mathrm{pH} 6$ The $\mathrm{pH}$ of working solution was then changed to $\mathrm{x}$. 5 and $\mathrm{pH} 9$ by acidification or adding of kase consequently (Table 2 , pH $6 \rightarrow \mathrm{pH} 5, \mathrm{pH} 6 \rightarrow \mathrm{pH} 9$ ). In this case spectroscopic properties of dye/DNA complexes $\left({ }^{\mathrm{em}} \lambda_{\max },{ }^{\mathrm{abs}} \lambda_{\max }\right.$ and $\left.S\right)$ were very alike. Probably all cyanines Cyan 41, Cyan 42 and TO interact with nucleic acids by similar mode. However, all dyes have low aggregation and high fluorescence 


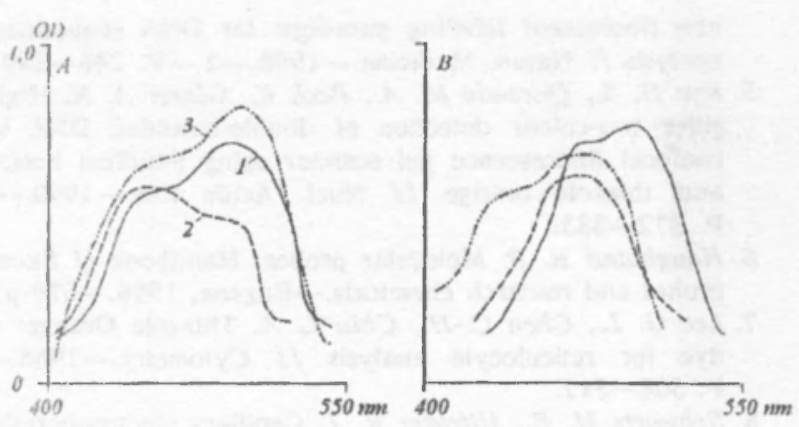

Fig. 4. The pH-depended absorption spectra of Cyan $41(A)$ and Cyan 42 iB) $(1-\mathrm{pH} 6 ; 2-\mathrm{pH} 5 ; 3-\mathrm{pH} 9)$

intensity in basic environment in contrast to acidic environment $\left({ }^{\mathrm{mol}} D /{ }^{\mathrm{agr}} \mathrm{D}, I\right)$.

In the second procedure, DNA solutions were prepared previously at $\mathrm{pH} 6, \mathrm{pH} 9$ and $\mathrm{pH} 5$ (Table $3)$. Working solutions were prepared by adding stock dye solution to nucleic acid solutions with various $\mathrm{pH}$. It was very surprising to observe change of colour of Cyan 42 (base) in basic environment ( $\mathrm{pH} \mathrm{9)}$ after its interaction with nucleic acid. Perhaps formation of dye-nucleic acid electrostatic complex is the first stage of cyanine dye-nucleic acid binding. Spectroscopic properties of formed complexes are very similar to those of romplexes prepared according to first procedure.

Recently we proposed possible mechanism of cyanine dyes-nucleic acids interaction [12]. As a rule asymmetric cyanines in aqueous solutions exists in the form of aggregation structures (dimers, trimers). We suppose cyanine dyes in aqueous solution to interact with nucleic acids in aggregated form. «Nucleic acid medium» disperses dye aggregates that resulted in the fixation of monomeric dyes.

As a rule asymmetric cyanine dyes are to represent dipoles because of their asymmetric arrangement of a charge. DNA also can be approximately considered as asymmetrically charged environment with negative charge located at sugar-phosphate backbone and positive charge in the interbase space. So we considered dipole-dipole interaction to play an important role in dye fixation.

«Nucleic acid medium» disperses dye aggregates resulting in the fixation of monomeric dyes. Intercalation of the dye into the double-stranded helix possibly takes place according to model of «half intercalation«. One heterocyclic part of cyanine intercalates, nestled between the adjacent base pairs, just when another heterocycle is spatially fixed by the groove of nucleic acid. We suppose that binting of heterocycle of higher basicity is caused by electrostatic interaction with phosphate group of nuclcic acid. The first stage of interaction is electrostatic external binding of the dyes aggregates. After that the heterocycle with low basicity intercalates into interbase space.

The increase of mixing ratio dye/nucleic acid results in the increase of $\mathrm{H}$-aggregates corcenlration in working solution with rise of aggregate bands («blue shift»). At the same time, nucleic acids can serve as scaffolds for the formation of $\mathrm{H}$-aggregates of another type for some dyes, with formalion of aggregation structures which are not observed for free dye. In this case new aggregate bands are observed in the spectrum. H-aggregates of this type $(n>2)$ were found for Cyan 13 (Fig. 3). Probably aggregates of stacking type could be formed on the accessible part of partly intercalated dye, i. e. heterocycle that was not placed between base pairs of nucleic acid.

This model accounts well also for the $\mathrm{pH}$ depended experiments with cyanine dyes (Tabl. 3). Acidic medium decreases coulombic interaction between helerocyclic bases of the dye and phosphate groups in the nucleic acid groove. In this case we observe an increase of dye aggregation and decrease of fluorescence intensity of dye complexes with nucleic acids. On the other hand, basic medium increases the nucleophilicity of nucleic acid phosphate groups in contrast to acidification. It causes strengthening of dye-nucleic acid complexes and increase of their fluorescence intensity.

So, model of partial intercalation of cyanine dyes can explain spectroscopic properties of cyanine complexes with nucleic acids.

Acknowledgements. We are grateful to Dr. I. Dubey for valuable discussions.

\section{С. М. Ярмолюк, В. Б. Ковальська, Ю. ГТ. Ковмун}

Взаємодія ціанінових барвників з нуклейновими кислэтами. 5. Модель жапівінтеркаляціћ монометинових ціаніновик барвників у дноспіральні нуклеїнові кислоти

\section{Резюме}

Нещодавно нами було запропоновано модель ннапівінтеркаляціі" монометинових чіанінових барвникіо у подвііну спіраль нукегїнових кислот. Бензтіазоловий гетероцикл жклесично» інтеркалюе, розташовуючись між комплементарними иарами основ, тоді як другий гетероцикл просторово фінсустирся в борозні нуклеїнової кислоти. Ми вважасмо, що гетероцикл з високою оснивністю розмішуетьсs в нуклеофільнішій бирозні, у той час як гетероцикл з мениою основністю вкинносться в мение електрофільний міжосновний простір. Меток представлених досліджень було визначення можливого способу фіксації другого гетероциклу в борозні нуклеїнової кислоти. Нами 
синпезовано $і$ вивчено низку структуроподібних ціанінових гарєників з різним розподілом едектронної густини. Ми вөажас.мо, ијо зв'язування другого гетероциклу з високою основністю зумовлюсться просторовою фікспцісю та його елекірростапичною взаємодією з фюсфатними групами нуклё̈нової кислоти. Монометиновиї піридинісвий барвник (Суап 40; 4-[(1-метилбензотіазоліліdен-2)метил]-1,2,6-триметил піридиніум тозілат) взасмодіяв з нативнон ДНК та РНК зі "начним зростанням інтенсивності флюоресценціі. Він, на наие погляд, є перспективним для розробки нових ціанінових іареникіа, що зө' язуються з нукцеїновими кислотами.

\section{С. М. Ярмолюк, В. Б. Ковальскач, КО. П. Кэвтун}

Взаимодействие цианиновьх красителей с нуклеиновыми кислотами. 5. Модель «полуинтеркаляция» монометиновых цияниновых красителей в двуспиратьные нуклеиновые кислоты Резнме

Недавно иами иредложена модепь "полуингиекаляции" мононетиновах цианиновых красителей в двойную спираль нуклеиновьх кислот Бензотиазоловый гетероцикі "классически" инперісалирует, расположившись между компгементарными парамін оснований. в то время как другой гетероцикл пространстөенно фиксируется в бороздке нуклеинс'вой кислоты. Мы смипаем, ито гетероцикл с большей основностью располагавтслі в более нуклеофильной бороздке, тогда как гетероцикл с иеньией основностью встраивается в электрофильное межос'овное пространство. Представленные исследования были награвлены на определение возможного способа фиксации гетероникла с больией основностью в бороздке нук.леиновой кислотьЈами синтезирована и изучена серия струкпуроподобных циачинсвых красипелей с разным распределением электронной ¿лоптности. Мы считаем, цто связывание гетероцикла с гіольмей основностью происходит за счет пространственной iьиксации и электростатического взаимодействия с фосфатчьми группами нуклеиновой кислотю. Взаимодействие монометинового пиридинового красителя Cуап d0 (4-I(метилбензотиазольлиден-2)метил]-1,2,6-мриметилпиридиниум този:ат) с натизной ДНК и РНК сопровождается значительным чозрастанием интенсизности флюоресценции. На наш взгляд, зтоп краситель нөляется перспективным для разработки на его основе нозых цианинов, взаимодействуюицих с нук.леиновыми кислотами.

\section{REFFIRENCES}

1. Gilden D. H., Vafai A., Shtram Y. Varicella zoster virus DNA in human sensory ganglia-Nature, 1983.-306. - P 478480.

2. Fischer $S$. G., Lerman $L$. S. DNA fragments differing by single base-pair substitutions are separated in denaturing gradient gels: correspondence with melting theory // Proc. Nat. Acad. Sci. USA. - 1983. -80.-P. 1579.

3. Durst $M$, Gissmann M., Ikenberg $H$. A papillomavirus DNA from a carcinoma and its prevelence in cancer biopsy samples from different gengraphic regions // Ibid.-P. 3812 .

4. Ju J. Glazer A. N., Mathies R. A. Energy transfer primer: A new fluorescent labeling paradigm for DNA sequencing and analysis // Nature Medicine.-1996. -2.-P. 246-249.

5. Rye H. S., Quesada M. A., Peck K. Glazer A. N. High-sensitive two-colour detection of double-stranded DNA with a confocal fluorescence gel scanner using ethidium homodimer and thiazole orange // Nucl. Acids Res.-1990.-19.P. 372-383.

6. Haughland R. P. Molecular probes. Handbook of fluorescent probes and research chemicals. - Eugene, 1996.-679 p.

7. Lee G. L, Chen C.-H., Chiu L. A. Thiazole Orange: a new dye for reticulocyte analysis // Cytometry.-1986.-7.P. 508-517.

8. Schwartz H. E., Ulfelder $K$. J. Capillary electrophoresis with laser-induced fluorescence detection of PCR fragments using Thiazole Orange // Anal. Chem.-1992.--64.-P. 17371740.

9. Carrlsson C., Larsson A., Jonsson $M$. et al. Optical and photophysical properties of the Oxazol Yellow DNA probes YO and YOYO // J. Phys. Chem.-1994.-98-P. 1031310321 .

10. Jacobsen J. P., Pedersen J. B., Hansen L. F., Wemmer D. E. Site selective bis-intercalation of a homodimeric thazole orange dye in DNA oligonucleotides // Nucl. Acids Res._1995.23. -P. 753-760.

11. Rye H. S., Glazer A. N. Interaction of dimeric intercalating dyes with single-stranded DNA // Ibid.-P. 1215-1222.

12. Yarmoluk S. M., Kovalska V. B., Smirnova T. V. et al. Interaction of cyanine dyes with nucleic acids. II. Spectroscopic properties of methyleoxy analogues of thiazole orange $/ /$ Biopolimery i kletka. $-1996 .-12$, N 6. - P. 74-81.

13. Hamer $F$. $M$. The cyanine dyes and related compounds. -New York: J. Willey, 1964.-790 p.

14. Rye H. S., Yue S., Wemmer D. E., Quesada M. A. Haughland $R$. P., Mathies $R$. A., Glazer A. N. Stable fluorescent complexes of double-stranded DNA with bis-intercalating asymmetric cyanine dyes: properties and applications // Nucl. Aclds Res. -1992._20.-P. 2803-2812.

15. Herz $A$. H. Dye-dye interactions of cyanines in solution and at $\mathrm{AgBr}$ surfaces // Photogr. Sci. and Eng.-1974.-18.P. 320-335.

16. Israelachvili J. Intermolecular and surface forces.-San Diegc: Acad. press. 1992. -P. 76-105, 122-133.

17. Ishchenko A. A. Structure and spectroscopic properties of polymethyne cyanine dyes.-Kyiv: Nauk. dumka. 1994 (in Russ). $-231 \mathrm{p}$.

18. Larsson A., Carlsson C., Jonsson, M., Albinsson B. Charac terization of the binding of the fluorescent dyes YO and YOYO to DNA by polarized light spectroscopy // J. Amer. Chem Soc. $-1994 .-116 .-P .8459-8465$.

19. Tyutyulkov N. Polymethine dyes - structures and proper ties.-Sofia: St. Kliment Ohridski Univ. press, 1991.P. $107-123$.

у

Received 09.02.98 